\title{
EVOLUTION AND MATERIAL CULTURE: A REPLY
}

Jan Apel \& Kim Darmark

To begin by summarizing the aims of our article, these were to (I) present what we believe to be the fundaments of evolutionary theory, (2) to present how studies of material culture can be related to evolutionary theory, and (3) to discuss what the advantages of such an evolutionary viewpoint might be in social studies.

The keynotes written by Thomas and Hegardt both see severe shortcomings with our article and the ideas presented within, while Nilsson Stutz in a more nuanced fashion points to some merits as well as some problematic issues with our thoughts.

All of the keynotes express a concern that evolutionary theory renders archaeology sterile and reductionist. Even though we certainly see the advantages of reductionist thinking in research, we are not of the opinion that evolutionary theory per se yields a sterile archaeology in which the actors are passive vehicles of transmitted information. Contrary to what some of the keynote writers emphatically maintain, that we are arrogant imperialist reactionaries who want to force everyone to conform to our ideas, our point was that evolutionary theory could constitute the framework in which to understand a multitude of diverse and detailed studies conducted in a way that is not the case today. Our concern is that focus often lies on the reconstruction of past contexts in minute detail for its own sake (cf. Riede 2006). This renders archaeology an incomplete ethnography, in which there is a strong temptation to stretch the evidence too far and in which there is no clear idea of the use of the vivid picture obtained. Furthermore, our opinion is that this focus on contextual detail to a certain degree is in opposition to what 
archaeology's major advantage is - the possibility to study human material culture over time spans not accessible to other disciplines. It seems that the discussion of whether or not evolutionary approaches are useful in archaeology rests upon differences in the view of the character of the archaeological source material and what types of questions it can answer. It is obvious that the participants in this discussion do not share a common definition of what archaeology is, and in this context we would like to make it clear that we regard archaeology as a subject that studies humans from their material remains. Julian Thomas' accusation that we regard cultural theory in other subjects as marginalized is simply based on a misunderstanding. What is important, however, is that many of the subjects that he refers to actually study human behaviour first hand and are thereby able to present robust theories of human cultural customs and behaviour based on observation. Archaeologists do not study living people but the scarce remains of material culture from peoples living in the past. If archaeologists pretend to be able to present holistic accounts of prehistoric cultures we will no doubt face the risk of becoming marginalized, since people outside of archaeology will recognize that our detailed accounts are not necessarily based on the archaeological source material but on ethnographic accounts or on our own experience of what it is to be human. We believe that if archaeology is to be considered relevant outside of our own field, it is crucial that the theories and hypotheses can be evaluated through studies of the archaeological source material.

Certainly, not all phenomena can be given evolutionary explanations. The unique installation of Barack Obama as president is not an event to be understood in terms of cultural evolution any more than the death of an individual frog or the occasional birth of a two-headed chicken is the interest of biological evolution. It is only in hindsight that we will be able to understand the impact of any of these unique events. Cultural variants appear all the time in human societies, as consequences of historically situated events, but variation alone does not constitute an evolutionary process. Heritability is also needed. We realize that the projectile point study included under the heading "selection and adaptation" in our article was not the best example of specific selective mechanisms at work, and that the example might come out as overly sterile, as Nilsson-Stutz argues. We certainly agree with her that it is of critical importance to reach a more detailed understanding of the environments in which the origin, transmission and selection of 
cultural variants take place. The inclusion of this example was done not so much to discuss the particular mechanisms at work in each instance, but to illustrate that there exist considerable cross-cultural regularities in the evolution of material culture, showing selection at work. This is a point that we feel is underestimated in the current academic climate, where such patterns are hidden under the banner of a contextualism which is counteractive to comparative research in time and space.

This contextualism is also explicit in Thomas' critique concerning the notion of culture as "holistic" versus "atomistic". In Thomas' words, "The most serious error in [Apel \& Darmark's] argument lies in this characterisation of culture as a set of monadic entities". We do not believe that cultural traits are transmitted as unchanged entities, jumping from brain to brain, changing these brains in a similar way and resulting in exactly the same phenotypical outcome. Certainly, elements of culture are renegotiated when arriving in new contexts. As researchers we have a choice, however, to stress either the similarities or the differences, to link different contexts together or to see them as incompatible.

In relation to this, we agree with Thomas in his statement that the Pitted Ware people did not conform to a pre-existing typology when they created their projectile points, if he by this means that the longterm development sketched by us is not guided by a teleological process in which the early points are to be seen as "incomplete" versions of the later ones. This does not seem to be his point, however, and we find his assertion curious when he says that "... practices do not involve the imposition of an abstract template onto inert matter..." Of course it does. The striking similarities between artefacts over large geographical and chronological distances, which we as archaeologists frequently encounter, are the result of the fact that people have conformed to abstract emic models in shaping their material products. Possibly this abstract template is what Thomas refers to as "a useful or pleasing outcome", the nature of which surely is decided by the context. How individual people have interpreted and experienced these abstract templates is a different matter. Thomas sees an incompatibility between cultural transmission theory and practice theory as described by Bourdieu. We believe this is because he overemphasizes the atomistic, discrete character of the units of transmission - i.e. the cultural ideas - which we believe to be the stuff that cultural evolution works with. Cultural evolutionary theory might be less straightforward with- 
out a rigid, all-encompassing definition of the units of transmission, but definitional vagueness does not make cultural evolutionary theory obsolete any more than ignorance of the gene before the modern evolutionary synthesis rendered evolutionary biology obsolete (Lyman \& O'Brien I998: 6I9).

Thomas points out that Franz Boas actually shared the ideas of the proponents of dual inheritance theory and that we erroneously connect him with post-processual ideas. This is an interesting comment that we would like to elaborate upon even though we still maintain that the connection between post-processualism and Boas - cultural relativism - is real. Many social scientists, such as Boas or Emilé Durkheim who have been regarded as harbouring anti-evolutionary ideas because they rejected ideas of unilinear I 9 th-century social evolution, were in fact inspired by Darwin's theory of biological evolution. Such an interest in evolutionary theory is also present in Pierre Bourdieu's sociology, especially when he discusses historical developments of different kinds of social institutions, for instance the development of the modernist movement "L'art pour l'art" during the i 9 th century (Bourdieu 2000). Here, the development of a modernist individual habitus (ontogeny) is related to the homologous development of a collective modernist field of art (phylogeny). Thus, we can only agree with Thomas when he suggests that Bourdieu's theory of social change is interesting for archaeologists. However, we suggest that the reason why we might be misled to believe that Bourdieu's sociology, or other action theories, cannot be reconciled with evolutionary principles is that such theories often are applied to contemporary situations. When they are applied to history, they are, as we see it, consistent with evolutionary thinking.

Hegardt's main issues with our article are that evolution, when applied to culture, is dangerous and that there is an external world waiting for scientists to describe the past in an evolutionary manner, so that this can be exploited (for evil). He even interprets the fact that much effort is put into stressing the differences between modern evolutionary theory and igth-century cultural evolution as irrefutable proof of the contrary. There must be similarities, he says, and based on this he seems to take the stance that modern evolutionary theory probably has a hidden agenda, and that the practice of denouncing earlier evolutionary theory is the academic equivalent of a wolf in sheep's clothing.

This ethical view permeates his entire text, and it seems that what Hegardt desires is an archaeology devoid of all relevance. First of all, 
if we are required to guarantee that not a single person can misuse our work, it is hard to see how we can write texts with any substance at all in them. Texts which are collectively recognized to be fictional will be hard to exploit for one's own cause, but as soon as the texts claim scientific value there arises the risk of them being used in ways not intended by the author. We hope that Hegardt's proposition is not that we write fiction.

Hegardt further rightly points out that evolutionary theory can be used to explain why some people today live in rich worlds and others in poor ones. This was done by Jared Diamond in his book Guns, Germs and Steel (2004 (I997)), and it explicitly denounces popular ideas of fundamental racial differences between people as an explanation, contrary to what Hegardt thinks will be the case with evolutionary explanations. Another very illuminating example is Joseph Heinrich's article "Demography and Cultural Evolution: How Adaptive Cultural Processes Can Produce Maladaptive Losses: The Tasmanian Case" (2004). Tasmania became an island at the end of the last Ice Age and the population, originally deriving from mainland Australia, became isolated. When the island was discovered by Europeans, the people living there had the simplest technology imaginable, consisting of 24 objects in total. Fishing and clothing technologies were unknown, but archaeological research has shown clear evidence of more complex technological assemblages on Tasmania before the arrival of the Europeans. Heinrich rejects adaptionist explanations to this and he certainly does not consider Hegardt's "foundational differences between people". Instead he presents a model of cultural evolution, in which he shows how technological complexity is related to the size of the pool of cultural learners - i.e. demographic factors - and which explains how complex technologies are hard to maintain in very small, isolated populations. This explanation is in no way based on an idea of foundational differences, but can on the contrary be used as a very powerful argument against such proposals!

So, we maintain that the solution to Hegardt's problem with the potential misuse of evolutionary theory is not to discard notions of evolution in the academic world, thus letting media, politicians and the public keep ideas based on an outdated form of evolutionary thinking. If we, as Hegardt ardently defends, have an ethical responsibility, it is to educate people and challenge vulgar interpretations of evolution. In this sense, we certainly do propose a restriction of perspectives, as 
we are accused of doing since evolutionary theory "cannot exist side by side with other perspectives". It is curious, however, that Hegardt does not realize that he strongly hints at a desire to restrict perspectives himself in his final suggestion.

Hegardt's obvious desire to minimize the impact of evolutionary thought on Scandinavian archaeology might become true, if we are to believe Nilsson Stutz in her clever introduction where she presents her doubts that evolutionary archaeology will obtain replicative success in Scandinavia. This is a relevant observation and might be true as well, especially since the subject lacks a common definition among its practitioners. Some of us study prehistoric artefacts while others study the history of archaeology, and still others study philosophical questions such as that of Heidegger's being. The only thing uniting us is that we are all archaeologists. This might be seen as convenient since it permits us all to work with things we like. However, one effect of the lack of a common ground to stand on is that social aspects, in no way connected with the scientific ideas we represent, will affect the replicative success of different theoretical propositions. This was, for instance, observed by Per Persson as early as 1999 in relation to evolutionary archaeology.

Based on sociological observations, not least by Pierre Bourdieu and his students, we allow ourselves to speculate on how evolutionary approaches to archaeology might be received in Sweden. Since humans tend to copy the behaviour of successful individuals, we would expect that the younger generation of archaeologists would rather copy our proponents in this debate than us. We couldn't help but notice that the commentators, which are more or less negative towards our ideas, have the following titles: professor, associate professor and lecturer, while Apel is a lecturer and Darmark a doctoral student. There is a significant imbalance of power, and we are inclined to agree with Nilsson Stutz that the chances of evolutionary ideas surviving and developing in Scandinavian archaeology might be slim. However, such a scenario would not necessarily be dependent on whether or not the new theoretical approach carries any scientific value. On the other hand, Bourdieu has also suggested that some younger students within a scientific field might break with tradition and choose a higher, more uncertain career orbit (Broady 1988). In doing so they will avoid following in the footsteps of earlier successful generations and thereby risk landing in the periphery of the field. However, if they succeed the rewards are massive, 
career wise. Thus there is always the chance that some of the younger participants in the field choose to follow the underdogs and reject the ideas of what would appear to be an older, tired, conservative generation, perhaps in the hope that a higher career orbit will pay off in the end. We eagerly await the future, and in response to Hegardt's question, we do "subordinate ourselves" to the fact that the selective environment in this case might not be favourable for our ideas, which will consequently be weeded out according to Darwinian principles.

\section{References}

Broady, D. 1988. Kulturens fält. Om Pierre Bourdieus sociologi. NORDICOMNytt/Sverige nr T-2. Pp 59-88.

Bourdieu, P. 2000 . Konstens regler. Det litterära fältets uppkomst och struktur. Stockholm/Stehag: Brutus Östlings bokförlag.

Diamond, J. 2004. Vete, vapen och virus: en kort sammanfattning au mänsklighetens historia under de senaste I 3000 åren. Stockholm. Pan. [Original title: Guns, germs and steel: the fates of human societies. London. Cape.]

Henrich, J. 2004. Demography and Cultural Evolution: How Adaptive Cultural Processes can Produce Maladaptive Losses - The Tasmanian Case. American Antiquity, Vol. 69, No. 2. Pp. 197-214.

Riede, F. 2006. Chaîne Opératoire, Chaine Evolutionaire? Putting Technological Sequences into an Evolutionary Perspective. Archaeological Review from Cambridge Vol. 2 I, No. 1. Pp. 5i-75.

Persson, P. r999. Arkeologi och evolutionism. In: Gustavsson, A. \& Karlsson, H. (Eds.), Glyfer och arkeologiska rum - en vänbok till Jarl Nordbladh. Göteborg. Pp. $667-678$.

Lyman, R.L. \& O’Brien, M.J. . 998 . The Goals of Evolutionary Archaeology: History and Explanation. Current Antbropology, Vol. 39, No. 5. Pp. 61 5-652. 
ANintCLLES 